\title{
Service Encounter Conceptualisation: Employees' Service Behaviours and Customers' Service Quality Perceptions
}

\section{Andrew M. Farrell}

Corresponding Author

Marketing Group

Aston Business School

Aston University

Birmingham, B4 7ET

United Kingdom

Phone: 00441213593011 ext. 5019

Fax: 00441213334313

Email: farrelam@aston.ac.uk

\section{Anne L. Souchon}

Marketing Group

Aston Business School

Aston University

Birmingham, B4 7ET

United Kingdom

Phone: 00441213593011 ext. 5060

Fax: 00441213334313

Email: a.I.souchon@aston.ac.uk

Geoffrey R. Durden

Graduate School of Management

La Trobe University

Melbourne

Victoria 3086

Australia

Phone: 0061394582755

Fax: 0061394782575

Email: g.durden@latrobe.edu.au 


\section{Service Encounter Conceptualisation: Employees' Service Behaviours and Customers' Service Quality Perceptions}

\section{Introduction}

According to recent figures, services account for over fifty percent of gross domestic product in the USA and many European countries, and over one quarter of world trade (Winsted, 2000). With this in mind, and considering that "levels of service which may have been tolerated only a generation ago are now regarded as unacceptable" (Donnelly and Shiu, 1999, p. 498), the improvement of service quality is paramount to services marketers.

Service quality represents a customer's assessment of the overall level of service offered by an organisation (Parasuraman et al., 1988), and this assessment is often based upon perceptions formulated during service encounters (Bitner et al., 1990; Johnston, 1995). The term service encounter is used to denote person-toperson interactions between a customer and an employee of an organisation during the purchase of a service (Bitner, 1990, Bitner et al., 1994).

Employee attitudes have sometimes been argued to affect service quality (e.g., Hartline and Ferrell, 1996), but this research circumvents the underlying logic that there must be mediating variables between employee attitudes and customers' perceptions of service quality. More specifically, it stands to reason that a customer will, in part, evaluate service quality on the basis of what an employee does (i.e., his or her behaviours) rather than what an employee thinks or feels (i.e., his or her attitudes), though employees' attitudes and behaviours will undoubtedly be related. For example, employees' service behaviours are influenced by employees' job satisfaction (Bettencourt and Brown, 1997) and moods at work (Kelley and Hoffman, 1997). These behaviours on the part of a service employee can be 
thought of as service quality implementation (SQI) behaviours, as they represent the behaviours associated with the implementation of an organisation's service quality provision policy. However, there is currently no consensus in the literature regarding what actually constitutes these SQI behaviours (Bitner et al., 1994; Bitner et al., 1990). Therefore, the objective of this study is to examine how front-line employees' SQI behaviours can affect customers' perceptions of service quality. In order to achieve this, all employee-related SQI factors need to be considered. By doing this, the paper provides a more comprehensive conceptualisation of factors affecting service quality than is currently available. This is achieved by the dyadic nature of the SQI conceptualisation, considering employees' service behaviours and customers' perceptions of service quality. The subsequent comprehensiveness of this conceptualisation gives distinct advantages to the study of service quality provision by providing a more detailed assessment of the factors that influence service quality. Therefore, organisations will be able to target their service delivery efforts in a more specific manner than was previously possible. To meet the objective outlined above the paper will now review the relevant literature, followed by a presentation of the dimensions of SQI behaviours.

\section{Literature Review: The Service Encounter}

Service encounters involve interaction between customers and employees (Bettencourt and Brown, 1997; Chandon et al., 1997; Price et al., 1995; Wels-Lips et al., 1998; Winsted, 2000) so employees will have an important role to play in influencing customers' perceptions of service encounters (c.f., Bitner et al., 1990; Johnston, 1995; Lytle et al., 1998). 
Service quality has, in the past, been conceptualised and operationalised in terms of what customers value in the encounter (e.g., Parasuraman et al., 1988; Winsted, 2000). For instance, customers have been shown to evaluate service quality on dimensions such as concern and civility (Winsted, 2000), listening and understanding demonstrated by the employee (Chandon et al., 1997), and employee attentiveness and perceptiveness (de Ruyter, and Wetzels, 2000). As a result, an overlap exists between the concept of service quality per se and that of employee SQI behaviours. In fact, a close inspection of the service quality scales shows that the majority of the items intended to capture service quality relate to human interaction elements of service delivery (Bitner et al., 1990). For example, drawing from the service quality scales, items such as "you do not receive prompt service from XYZ's employees," "employees of XYZ are polite," and "employees of XYZ do not give you personal attention" (Parasuraman et al., 1988) clearly demonstrate a large proportion of human interaction-specific content. Therefore, it seems as though any conceptualisation of SQI needs to take into account both the behaviours of service employees and the perceptions of customers.

Customers' perceptions of service quality will be based almost entirely upon the SQI behaviours of employees (c.f., Bitner et al., 1990; Parasuraman et al., 1988, 1985). Employee SQI behaviours represent the service delivery process, or the functional quality (Grönroos, 1984), while customers' assessments of service quality represent an evaluation of the service delivery process, or the technical outcome (Grönroos, 1984). Service encounter research has yet to provide a dimensional articulation that comprehensively assesses the relevant behaviours of employees as well as customers' evaluations in a formulation of service quality perceptions. 
In order to derive as comprehensive as possible a delineation of SQI behaviours, both service encounter and service quality literature strands were reviewed. Eleven employee and 38 customer factors were identified. Definitions of these factors and relevant scale item wordings were examined and enabled the conceptual exercise of grouping together respective factors to form higher order dimensions that represent the behavioural implementation of an organisational service quality policy. Hence, items deemed to be measuring similarly defined and operationalised employee or customer factors were conceptually amalgamated. This exercise resulted in eleven dimensions that comprise behavioural SQI. These dimensions (adaptability, assurance, civility, customer orientation, empathy, recovery, reliability, responsiveness, spontaneity, tangibles, and teamwork) are presented in Table 1, together with the literature from which they were generated. Table 1 provides a more complete and generalisable conceptualisation of factors influencing customers' perceptions of service quality than has previously been available as the SQI dimensions are drawn from a wide variety of service industry contexts. All of the SQI behaviour dimensions are likely to influence customers' perceptions of service quality, as modelled in the subsequent section.

\section{(please take in Table 1 about here)}

\section{Development of Hypotheses}

The following section develops hypotheses that relate SQI behaviours to customers' overall evaluation of service quality. The development of each hypothesis is based upon the literature reviewed and summarised in Table 1. 
Previous research into service encounter interaction has highlighted the importance of employees being flexible and adapting their behaviours to meet the changing needs and requests of customers. This relationship has been both theoretically proposed (e.g., Hartline and Ferrell, 1996) and empirically validated (e.g., Bitner et al., 1994; Bitner et al., 1990). Employees need to be able to recognise customers' needs and inappropriate or inadequate treatment of such situations can result in dissatisfaction (Bitner et al., 1994; Bitner et al., 1990). Although service that the customer sees as special may be regarded as routine service behaviour by the employee it is necessary for employees to recognise that customers' special needs are important and that adapting to meet those needs is critical (Zeithaml and Bitner, 2000). Adaptability can be viewed as a continuum, ranging from total conformity to organisational policy, through to complete service personalisation (Hartline and Ferrell, 1996). Therefore, an employee can display varying degrees of adaptability depending upon what customers require from service situations. However, in general, the more an employee attempts to adapt their behaviours to suit customers' needs, the more favourably the customer is likely to evaluate the quality of service delivery (c.f., Bitner et al., 1994; Bitner et al., 1990; Hartline and Ferrell, 1996; Zeithaml and Bitner, 2000). Hence, the following is proposed:

$\mathrm{H}_{1}$ : The greater the adaptability of service employees, the greater customers' perceptions of service quality.

The work linking feelings of assurance with greater perceptions of service quality is extensive (e.g., Cronin et al., 2000; Johnston, 1995; Parasuraman et al., 1988). 
However, this only takes into account the feelings of customers, not the behaviours of service employees. Customers like to be kept informed during service processes (Parasuraman et al., 1985), as it gives them increased feelings of confidence (Parasuraman et al., 1988). Employees who behave in an assuring manner also increase customers' feelings of security and perceptions of employee integrity and competence (Johnston, 1995). If customers like to feel assured and service employees behave in a reassuring manner this should lead to more favourable evaluations of service quality from customers. Based on this, the following is put forward:

$\mathrm{H}_{2}$ : The greater the assurance given by service employees, the greater customers' perceptions of service quality.

Customer research has found that civil behaviour from employees generates more favourable service quality and satisfaction perceptions from customers (e.g., Guiry, 1992; Johnston, 1995; Dabholkar et al., 2000). When employees are attentive, courteous, cooperative, and keen to listen customers' service quality perceptions are greater whereas if employees appear disinterested customers' service quality perceptions suffer (c.f., Guiry, 1992). Therefore, the following is hypothesised:

$\mathrm{H}_{3}$ : The greater the civility of service employees, the greater customers' perceptions of service quality.

Saxe and Weitz (1982) were among the first to highlight the need for organisations to encourage employees to adopt a customer orientation, whereby employees 
should avoid actions that sacrifice customer interest in order to increase organisational performance. Recent work has validated this notion by showing that customers believing employees to be highly customer oriented have higher perceptions of service quality, since they consider that the employees are more interested in their welfare (Kelley and Hoffman, 1997). This can be summarised by the following proposition:

$\mathrm{H}_{4}$ : The greater the customer orientation of service employees, the greater customers' perceptions of service quality.

Various studies have examined the effects of service recovery strategies and behaviours upon customers' satisfaction and service quality perceptions (e.g., Bitner et al., 1990; Boshoff and Allen, 2000). It seems that the ability of employees to respond effectively to customer complaints or service failures can result in increased levels of service quality (Bitner et al., 1994; Lytle et al., 1998). The content and form of the employee's response to the service system failure causes the incident to be remembered either favourably or unfavourably (Bitner et al., 1994; Bitner et al., 1990; Zeithaml and Bitner, 2000). The theory behind this is that when a customer experiences a problem with an organisation, their confidence in, and willingness to frequent, that organisation suffers (Lytle et al., 1998). However, the response of an organisation can restore the customer's confidence, or lessen it if failure is repeated (Berry et al., 1990). Based upon this argument, the following is put forward:

$\mathrm{H}_{5}$ : The greater the recovery performance of employees, the greater customers' perceptions of service quality. 
Certain authors propose that to continually surprise customers with levels of service given is necessary for customer retention and increased perceptions of service quality delivered (c.f., Bitner et al., 1990). Previous empirical work has demonstrated that such "special treatment" from employees is a source of both satisfaction and service quality (Zeithaml and Bitner, 2000). One particular study has highlighted that "even when customers have no special need or request, customers remember with considerable frequency those occasions when they receive special treatment by the service employee" (Bitner et al., 1990, p. 80). Indeed, the same study found that $43.8 \%$ of satisfactory service encounters reviewed were as a result of customer delight with unprompted or unsolicited employee actions (Bitner et al., 1990). By making service encounters memorable through such spontaneous treatment of customers, employees in effect campaign for their organisation the next time a customer needs to choose an organisation to meet their needs. This leads to the following being proposed:

H6: The greater the spontaneity of employees, the greater customers' perceptions of service quality.

High performing groups are often characterised by teamwork and it is the focus of several firms known for their outstanding customer service (Zeithaml et al., 1988). The physical demands of service work can be draining for service employees (Berry et al., 1990) and the supportiveness of colleagues can both motivate and enable employees to continue to perform good service (King and Garey, 1997). The presence of a community spirit in the workplace is a powerful antidote to service 
burnout effects (Berry et al., 1990). High levels of teamwork have, however, resulted in employees overestimating customers' service expectations (Baker and Fasenmaier, 1997). Hence, teamwork is viewed as important, but organisations should be careful not to forget about customers in their efforts to help each other. Based upon the previous argument, the following proposition is presented:

$\mathrm{H}_{7}$ : The greater the teamwork of employees, the greater customers' perceptions of service quality.

The ability of employees to empathise with customers has also been associated with greater perceptions of service quality (Caruana et al., 2000; Mohr and Bitner, 1991; Price et al., 1995). Empathy is displayed by employees who are approachable (Parasuraman et al., 1985), caring (Johnston, 1995), understanding (Chandon et al., 1997), and make an effort to understand customers' needs (Wels-Lips et al., 1998). This relationship is hypothesised as follows:

$H_{8}$ : The greater the empathy of service employees, the greater customers' perceptions of service quality.

Amongst American studies of service quality, reliability has consistently been identified as the most important determinant of perceptions of service quality (Parasuraman et al., 1988; Zeithaml and Bitner, 2000). Employees need to maintain consistency of service performance, to be dependable and accurate when dealing with customers (Parasuraman et al., 1985). Therefore, if employees can deliver services as reliably as possible, doing things "right the first time" (Dabholkar et al., 
1996) customers' perceptions of service quality should favourably reflect this commitment. This leads to the following:

$\mathrm{H}_{9}$ : The greater the reliability of service employees, the greater customers' perceptions of service quality.

Responsiveness is a willingness to help customers and to provide prompt service (Zeithaml and Bitner, 2000). This aspect of employee behaviour has once again been associated with increased perceptions of service quality on the part of customers (e.g., Cronin and Taylor, 1992; de Ruyter et al., 1997; Wels-Lips et al., 1998). From research, the more willing employees appear to help customers, and the faster the service is delivered, the greater customers' perceptions of service quality (Cronin et al., 2000; Parasuraman et al., 1988), hence the following is put forward:

$\mathrm{H}_{10}$ : The greater the responsiveness of service employees, the greater customers' perceptions of service quality.

Tangibles represent the physical aspects of the service delivery: e.g., the aesthetics and cleanliness of the facility, the neatness of employees' dress (Parasuraman et al., 1988, 1985; Johnston, 1995). It might at first appear confusing to associate employees' behaviours during a service encounter with customers' perceptions of tangibles. However, employees should still be partly responsible for presenting high quality tangibles to customers. For instance, employees can make a commitment to dress to an appropriate standard, or can clean the physical facilities present during 
service encounters, both of which should impact upon customers' perceptions of tangibles. Therefore, employees can contribute towards customers' perceptions of service quality, via tangibles, as presented below:

$\mathrm{H}_{11}$ : The greater customers' perceptions of tangibles, the greater their perceptions of service quality.

The hypotheses are presented diagrammatically in Figure 1.

Figure 1. A Conceptualisation of Service Quality Implementation

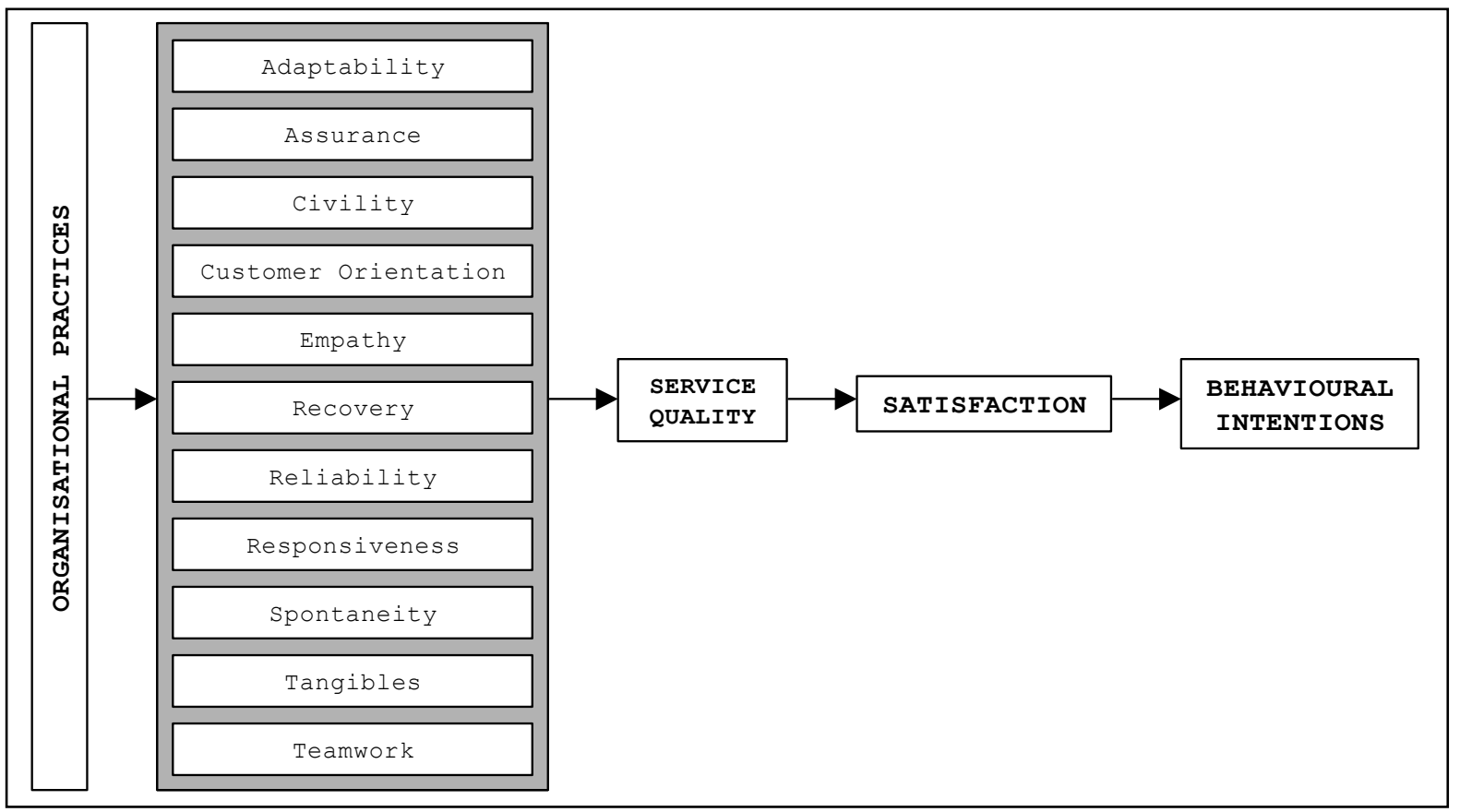

It should be noted that the construct 'organisational practices' is included to represent all factors related to the organisation that can occur prior to the service encounter that may influence the implementation of service quality initiatives (i.e., managerial conduct or employees' attitudes, such as job satisfaction or organisational commitment). It is not the purpose of this paper to examine these factors, merely to recognise that they exist and may influence the delivery of high 
quality service during service encounters (c.f., Hartline and Ferrell, 1996; Zeithaml and Bitner, 2000). The outcome variables for service encounter interactions are generally considered to include perceptions of service quality, customer satisfaction, and customers' behavioural intentions (see Figure 1). The studies reviewed for this paper alone demonstrate that there is considerable argument as to the order in which these constructs impact upon customers' behavioural intentions (see Table 2). As indicated, some authors propose that service quality serves as an antecedent to satisfaction (e.g., Andreassen and Lindestad, 1998; Chenet, Tynan, and Money, 2000; Cronin and Taylor, 1992; Dabholkar, Shepherd, and Thorpe, 2000; de Ruyter, Bloemer, and Peeters, 1997; de Ruyter, Wetzels, Lemmink, and Mattsson, 1997; Ennew and Binks, 1999; Fornell, Johnson, Anderson, Cha, and Bryant, 1996; Gotlieb, Grewal, and Brown, 1994) whereas others believe satisfaction precedes service quality (e.g., Athanassopoulos, 2000; Bitner, 1990; 
Table 2. Customers' Behavioural Intentions, Satisfaction, and Service Quality

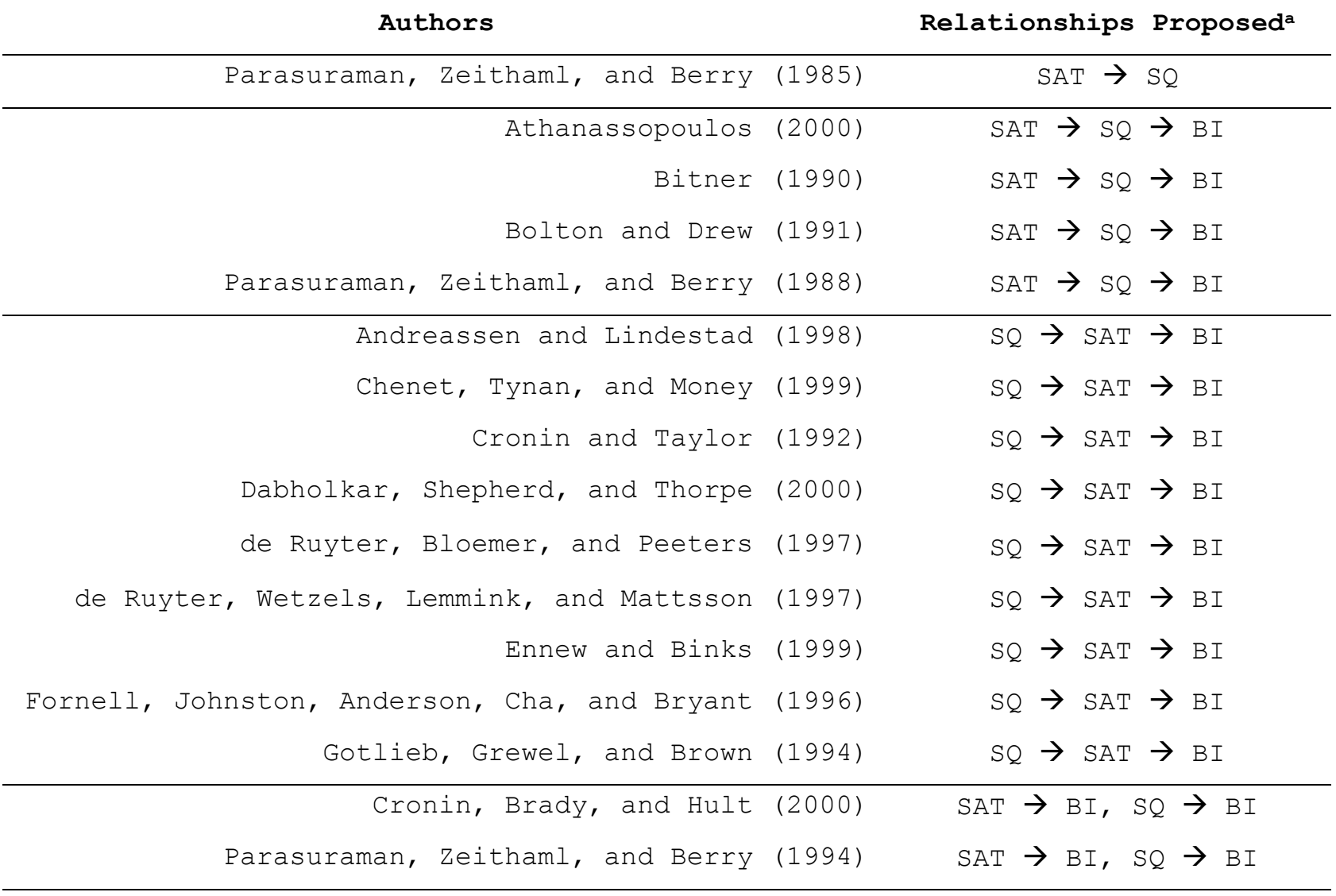

a $\mathrm{SAT}=$ Satisfaction, $\mathrm{SQ}=$ Service Quality, $\mathrm{BI}=$ Customers' Behavioural Intentions

Bolton and Drew, 1991; Parasuraman, Zeithaml, and Berry, 1988, 1985). Further work has revealed that service quality and satisfaction have direct relationships with behavioural intentions, with less emphasis placed upon mediating effects (e.g., Cronin, Brady, and Hult, 2000; Parasuraman, Zeithaml, and Berry, 1994). However, it is not the purpose of the current study to resolve the conceptual issue of service quality, customer satisfaction, and customers' behavioural intentions. Simply, in this paper, the order adopted in Figure 1 is based upon the fact that the majority of recent studies in Table 2 (i.e., those from 1992 onwards) favour service quality preceding satisfaction which leads to customers' behavioural intentions (e.g., Chenet, Tynan, and Money, 2000; Cronin and Taylor, 1992; Dabholkar, Shepherd, 
and Thorpe, 2000; de Ruyter, Bloemer, and Peeters, 1997; de Ruyter, Wetzels, Lemmink, and Mattsson, 1997; Gotlieb, Grewal, and Brown, 1994).

\section{Implications and Future Research Directions}

This new approach to service quality implementation offers academic significance in that it conceptualises service quality assessment from two sides, that of the employee attempting to utilise service quality initiatives and from the overall service quality assessments of customers. This research provides a useful platform from which future service encounter research may build. For practitioners, the study highlights the importance of service employees' behaviours in customers' formulations of service quality perceptions. Secondly, the implementation of service quality principles is not just focussing on customers' perceptions of service quality, as much of the previous work has done. The current conceptualisation details a behavioural construct, offering precise practical guidance for organisational practices that should enhance service quality offerings. This has implications for both employee recruitment and training, as managers can concentrate on hiring employees who display appropriate behavioural characteristics or implement training programs designed to enhance particular employee behaviours. Future research is now necessary to empirically validate the relationships proposed in this paper, to see if the dimensions of service quality implementation will have the hypothesised effects upon customers' perceptions of service quality. This research could be undertaken as, for instance, a dyadic mail survey of service employees and customers. Further research could also seek to examine the effects of managerial inputs (e.g., empowerment of service workers, leadership) upon the quality of frontline employees' SQI performance. As it now stands, this paper represents a base 
from which future research into customer satisfaction, service quality, and service delivery on the part of employees and managers can be undertaken.

\section{References}

Andreassen, T. W. and Lindestad, B. (1998), "Customer Loyalty and Complex Services: The Impact of Corporate Image on Quality, Customer Satisfaction and Loyalty for Customers with Varying Degrees of Service Expertise," International Journal of Service Industry Management, 9, 8, pp. 7-23

Athanasopoulos, A.D. (2000), "Customer Satisfaction Cues To Support Market Segmentation and Explain Switching Behavior," Journal of Business Research, 47, pp. 191-207

Baker, D. and Fesenmaier, D.R. (1997), "Effects of Service Climate on Managers' and Employees' Rating of Visitors' Service Quality Expectations," Journal of Travel Research, Summer, pp. 15-22

Berry, L.L., Zeithaml, V.A., and Parasuraman, A. (1990), "Five Imperatives for Improving Service Quality," Sloan Management Review, Summer, pp. 29-38

Bettencourt, L.A. and Brown, S.W. (1997), "Contact Employees: Relationships Among Workplace Fairness, Job Satisfaction and Prosocial Behaviors," Journal of Retailing, 73, 1, pp. 39-61

Bettencourt, L.A. and Gwinner, K. (1996), "Customization of the Service Experience: The Role of the Frontline Employee," International Journal of Service Industry Management, 7, 2, pp. 3-20.

Bitner, M.J. (1990), "Evaluating Service Encounters: The Effects of Physical Surroundings and Employee Responses," Journal of Marketing, 54, April, pp. 6982 
Bitner, M.J., Booms, B.H., and Mohr, L.A. (1994), "Critical Service Encounters: The Employee’s Viewpoint," Journal of Marketing, 58, October, pp. 95-106

Bitner, M.J., Booms, B.H., and Tetreault, M.S. (1990), "The Service Encounter: Diagnosing Favorable and Unfavorable Incidents," Journal of Marketing, 54, January, pp. 71-84

Bolton, R.N. and Drew, J.H. (1991), "A Multistage Model of Customers' Assessments of Service Quality and Value," Journal of Consumer Research, 17, March, pp. 375-384

Boshoff, C. and Allen, J. (2000), "The Influence of Selected Antecedents on Frontline Staff's Perceptions of Service Recovery Performance," International Journal of Service Industry Management, 11, 1, pp. 63-90

Caruana, A., Ewing, M.T., and Ramaseshan, B. (2000), "Assessment of the ThreeColumn Format SERVQUAL: An Experimental Approach," Journal of Business Research, 49, pp. 57-65

Chandon, J-L., Leo, P-Y., and Philippe, J. (1997), "Service Encounter Dimensions A Dyadic Perspective: Measuring the Dimensions of Service Encounters as Perceived by Customers and Personnel," International Journal of Service Industry Management, 8, 1, pp. 65-86

Chenet, P., Tynan, C., and Money, A. (2000), "The Service Performance Gap: Testing the Redeveloped Causal Model," European Journal of Marketing, 34, 3/4, pp. $472-495$

Cronin, J.J., Brady, M.K., and Hult, G.T. (2000), "Assessing the Effects of Quality, Value, and Customer Satisfaction on Consumer Behavioral Intentions in Service Environments," Journal of Retailing, 76, 2, pp. 193-218 
Cronin, J.J. and Taylor, S.A. (1992), "Measuring Service Quality: A Reexamination and Extension," Journal of Marketing, 56, July, pp. 55-68

Dabholkar, P.A., Shepherd, C.D., and Thorpe, D.I. (2000), "A Comprehensive Framework for Service Quality: An Investigation of Critical Conceptual and Measurement Issues Through a Longitudinal Study," Journal of Retailing, 76, 2 , pp. $139-173$

Dabholkar, P.A., Thorpe, D.I., and Rentz, J.O. (1996), “A Measure of Service Quality for Retail Stores," Journal of the Academy of Marketing Science, 24, 1, pp. 3-16 de Ruyter, K., Bloemer, J., and Peeters, P. (1997), "Merging Service Quality and Service Satisfaction: An Empirical Test of an Integrative Model," Journal of Economic Psychology, 18, pp. 387-406

de Ruyter, K. and Wetzels, M.G.M. (2000), "The Impact of Perceived Listening Behavior in Voice-to-Voice Service Encounters," Journal of Service Research, 2, 3, pp. $276-284$

de Ruyter, K., Wetzels, M.G.M., Lemmink, J., and Mattsson, J. (1997), "The Dynamics of the Service Delivery Process: A Value-Based Approach," International Journal of Research in Marketing, 14, pp. 231-243

Dobni, D., Zerbe, W., and Ritchie, J.R.B. (1997), "Enhancing Service Personnel Effectiveness Through the Use of Behavioural Repertoires," Journal of Services Marketing, 11, 6, pp. 427-445.

Donnelly, M. and Shiu, E. (1999), “Assessing Service Quality and its Link with Value for Money in a UK Local Authority's Housing Repairs Service Using the SERVQUAL Approach," Total Quality Management, 10, 4/5, July, pp. 498-506 
Ennew, C.T. and Binks, M.R. (1999), "Impact of Participative Service Relationships on Quality, Satisfaction and Retention: An Exploratory Study," Journal of Business Research, 46, pp. 121-132

Fornell, C., Johnson, M.D., Anderson, E.W., Cha, J., and Bryant, B.E. (1996), “The American Customer Satisfaction Index: Nature, Purpose, and Findings," Journal of Marketing, 60 , October, pp. 7-18

Gotlieb, J.B., Grewal, D., and Brown, S.W. (1994), "Consumer Satisfaction and Perceived Quality: Complementary or Divergent Constructs?" Journal of Applied Psychology, 79, 6, pp. 875-885

Grönroos, C. (1984), "A Service Quality Model and Its Marketing Implications," European Journal of Marketing, 18, 4, pp. 36-44

Guiry, M. (1992), "Consumer and Employee Roles in Service Encounters," Advances in Consumer Research, 19, pp. 666-672.

Hartline, M.D. and Ferrell, O.C. (1996), "The Management of Customer-Contact Employees: An Empirical Investigation," Journal of Marketing, 60, October, pp. $52-70$

Jayasuriya, R. (1998), "Measuring Service Quality in IT Services: Using Service Encounters to Elicit Quality Dimensions," Journal of Professional Services Marketing, 18, 1, pp. 11-23

Johnston, R. (1995), "The Determinants of Service Quality: Satisfiers and Dissatisfiers," International Journal of Service Industry Management, 6, 5, pp. 5371

Kelley, S.W. and Hoffman, K.D. (1997), "An Investigation of Positive Affect, Prosocial Behaviors, and Service Quality," Journal of Retailing, 73, 3 pp. 407-427 
King, C. and Garey, J.G. (1997), "Relational Quality in Service Encounters," International Journal of Hospitality Management, 16, 1, pp. 39-63

Lytle, R.S., Hom, P.W., and Mokwa, M.P. (1998), "SERV*OR: A Managerial Measure of Organizational Service-Orientation," Journal of Retailing, 74, 4, pp. $455-489$

Mishra, D.O. (2000), "Interdisciplinary Contributions in Retail Service Delivery: Review and Future Directions," Journal of Retailing and Consumer Studies, 7, pp. $101-118$

Mohr, L.A. and Bitner. M.J. (1991), "Mutual Understanding Between Customers and Employees in Service Encounters," Advances in Consumer Research, 18, pp. 611-617.

Morrison, E.W. (1996), "Organizational Citizenship Behaviors as a Critical Link Between HRM Practices and Service Quality," Human Resource Management, 35, 4, pp. 493-512

Parasuraman, A., Zeithaml, V.A., and Berry, L.L. (1994), "Reassessment of Expectations as a Comparison Standard in Measuring Service Quality: Implications for Further Research," Journal of Marketing, 58, January, pp. 111124

Parasuraman, A., Zeithaml, V.A., and Berry, L.L. (1988), "SERVQUAL: A MultipleItem Scale for Measuring Consumer Perceptions of Service Quality," Journal of Retailing, 64, 1, pp. 12-40

Parasuraman, A., Zeithaml, V.A., and Berry, L.L. (1985), "A Conceptual Model of Service Quality and Its Implications for Future Research," Journal of Marketing, 49, Fall, pp. 41-50 
Price, L.L., Arnould, E.J., and Deibler, S.L. (1995), "Consumers' Emotional Responses to Service Encounters: The Influence of the Service Provider," International Journal of Service Industry Management, 6, 3, pp. 34-63

Saxe, R. and Weitz, B.A. (1982), "The SOcO Scale: A Measure of the Customer Orientation of Salespeople," Journal of Marketing Research, 19, August, pp. 343351

Schneider, B., White, S.S., and Paul, M.C. (1998), "Linking Service Climate and Customer Perceptions of Service Quality: Test of a Causal Model," Journal of Applied Psychology, 83, 2, pp. 150-163

Wels-Lips, I., van der Ven, M., and Pieters, R. (1998), "Critical Services Dimensions: An Empirical Investigation Across Six Industries," International Journal of Service Industry Management, 9, 3, pp. 286-309

Winsted, K.F. (2000), "Service Behaviors the Lead to Satisfied Customers," European Journal of Marketing, 34, 3/4, pp. 399-417

Zeithaml, V.A. and Bitner, M.J. (2000), Services Marketing: Integrating Customer Focus Across the Firm (2 ${ }^{\text {nd }}$ Edition), New York, McGraw-Hill

Zeithaml, V.A., Berry, L.L., and Parasuraman, A. (1988), "Communication and Control Processes in the Delivery of Service Quality," Journal of Marketing, 52, April, pp. 35-48

\section{About the Authors}

\section{Andrew Farrell}

Andrew Farrell is a Doctoral Candidate in Marketing at Aston Business School (UK). He holds BCA and BCA (Hons) degrees in Marketing from Victoria University of 
Wellington, New Zealand. His research interests include the effects of leadership upon services personnel and service quality delivery and enhancement.

\section{Dr Anne Souchon}

Dr. Anne Souchon is a Lecturer in Marketing and the Director of Undergraduate Marketing Studies at Aston Business School (UK), which she joined in January 1999. Examples of Anne's areas of research interests include: organisational information acquisition and utilisation, export marketing and export performance. Anne's work has been published in a variety of academic research outlets including the Journal of Business Research, the Journal of International Marketing, the Journal of Marketing Management, the International Marketing Review, and Advances in International Marketing. Anne is also the recipient of the 2000 Most Outstanding Paper Award for her 1999 article published in the International Marketing Review. Anne coordinates, and is actively involved in, joint research projects with academics from Austria, Germany, the UK, the USA, and New Zealand, in the distinct areas of export information use and relationship marketing.

\section{Geoffrey R Durden}

Geoff Durden is an Associate Professor in Marketing in the Graduate School of Management at La Trobe University (Australia), where he teaches marketing/international marketing and services marketing. His current research interests include: service quality evaluation in an Asian setting (Taiwan), leadership in a services setting and export information acquisition and use (a five nation study). 
He has published internationally, including the International Journal of Advertising and Advances in International Marketing. 
Table 1. Service Quality Implementation (SQI) Dimensions

\begin{tabular}{|c|c|c|c|c|c|}
\hline SQI DIMENSION ${ }^{1}$ & AUTHORS & $\begin{array}{l}\text { OUTCOME } \\
\text { VARIABLE }^{2}\end{array}$ & $\begin{array}{l}\text { LEVEL OF } \\
\text { ANALYSIS }{ }^{3}\end{array}$ & $\begin{array}{l}\text { STUDY } \\
\text { TYPE }^{4}\end{array}$ & INDUSTRIES STUDIED $^{5}$ \\
\hline $\begin{array}{l}\text { ADAPTABILITY } \\
\text { Response to Customer Needs }\end{array}$ & $\begin{array}{l}\text { Bitner, Booms, \& Tetreault (1990) } \\
\text { Bitner, Booms, \& Mohr (1994) } \\
\text { Hartline \& Ferrell (1996) } \\
\text { Bettencourt \& Gwinner (1996) } \\
\text { Zeithaml \& Bitner (2000) }\end{array}$ & $\begin{array}{l}\text { SAT } \\
\text { SAT } \\
\text { SQ } \\
\text { SQ } \\
\text { SQ }\end{array}$ & $\begin{array}{l}\mathrm{C} \\
\mathrm{E} \\
\mathrm{E} \\
---\end{array}$ & $\begin{array}{l}E \\
E \\
T \\
T \\
T\end{array}$ & $\begin{array}{l}2,13,22 \\
2,13,22 \\
--- \\
--- \\
---\end{array}$ \\
\hline $\begin{array}{l}\text { ASSURANCE } \\
\text { Authenticity } \\
\text { Comfort } \\
\text { Communication } \\
\text { Competence } \\
\text { Confidence } \\
\text { Credibility } \\
\text { Integrity } \\
\text { Promising } \\
\text { Security } \\
\text { Trust }\end{array}$ & $\begin{array}{l}\text { Parasuraman, Zeithaml, \& Berry (1985) } \\
\text { Parasuraman, Zeithaml, \& Berry (1988) } \\
\text { Cronin \& Taylor (1992) } \\
\text { Johnston (1995) } \\
\text { Price, Arnould, \& Deibler (1995) } \\
\text { Dabholkar, Thorpe, \& Rentz (1996) } \\
\text { Chandon, Leo, \& Philippe (1997) } \\
\text { de Ruyter, Bloemer, \& Peeters (1997) } \\
\text { Jayasuriya (1998) } \\
\text { Wels-Lips, van der Ven, \& Pieters (1998) } \\
\text { Schneider, White, \& Paul (1998) } \\
\text { Caruana, Ewing, \& Ramaseshan (2000) } \\
\text { Cronin, Brady, \& Hult (2000) } \\
\text { Dabholkar, Shepherd, \& Thorpe (2000) } \\
\text { de Ruyter \& Wetzels (2000) }\end{array}$ & $\begin{array}{l}\text { SQ } \\
\text { SQ } \\
\text { SQ, SAT } \\
\text { SAT } \\
\text { Emotions } \\
\text { SQ } \\
\text { SAT } \\
\text { SQ, SAT } \\
\text { SQ } \\
\text { SAT } \\
\text { SQ } \\
\text { SQ } \\
\text { SAT } \\
\text { SQ } \\
\text { SAT }\end{array}$ & $\begin{array}{l}\mathrm{C} / \mathrm{E} \\
\mathrm{C} \\
\mathrm{C} \\
\mathrm{C} \\
\mathrm{C} \\
\mathrm{C} \\
\mathrm{C} / \mathrm{E} \\
\mathrm{C} \\
\mathrm{E} \\
\mathrm{C} \\
\mathrm{C} \\
\mathrm{C} \\
\mathrm{C} \\
\mathrm{C} \\
\mathrm{C}\end{array}$ & $\begin{array}{l}E \\
E \\
E \\
E \\
E \\
E \\
E \\
E \\
E \\
E \\
E \\
E \\
E \\
E \\
E\end{array}$ & $\begin{array}{l}4,7,20,24 \\
4,7,20,24,26 \\
4,8,11,19 \\
4 \\
27 \\
23 \\
9 \\
12 \\
12 \\
9,12,14,21,22,27 \\
4 \\
27 \\
10,11,12,16,18,25 \\
6 \\
5\end{array}$ \\
\hline $\begin{array}{l}\text { CIVILITY } \\
\text { Attentiveness } \\
\text { Cooperation } \\
\text { Courtesy } \\
\text { Friendliness / Helpfulness } \\
\text { Indifference } \\
\text { Keen-ness } \\
\text { Listening } \\
\text { Perceptiveness } \\
\text { Personal Attention } \\
\text { Relationship }\end{array}$ & $\begin{array}{l}\text { Parasuraman, Zeithaml, \& Berry (1985) } \\
\text { Guiry (1992) } \\
\text { Johnston (1995) } \\
\text { Price, Arnould, \& Deibler (1995) } \\
\text { Dabholkar, Thorpe, \& Rentz (1996) } \\
\text { Chandon, Leo, \& Philippe (1997) } \\
\text { Schneider, White, \& Paul (1998) } \\
\text { Cronin, Brady, \& Hult (2000) } \\
\text { Dabholkar, Shepherd, \& Thorpe (2000) } \\
\text { de Ruyter \& Wetzels (2000) } \\
\text { Winsted (2000) }\end{array}$ & $\begin{array}{c}\text { SQ } \\
\text { SAT } \\
\text { SAT } \\
\text { Emotions } \\
\text { SQ } \\
\text { SAT } \\
\text { SQ } \\
\text { SAT } \\
\text { SQ } \\
\text { SAT } \\
\text { SQ }\end{array}$ & $\begin{array}{l}\text { C/C } \\
C \\
C \\
C \\
C \\
C / E \\
C \\
C \\
C \\
C \\
C\end{array}$ & $\begin{array}{l}\mathrm{E} \\
\mathrm{E} \\
\mathrm{E} \\
\mathrm{E} \\
\mathrm{E} \\
\mathrm{E} \\
\mathrm{E} \\
\mathrm{E} \\
\mathrm{E} \\
\mathrm{E} \\
\mathrm{E}\end{array}$ & $\begin{array}{l}4,7,20,24 \\
22,23 \\
4 \\
27 \\
23 \\
9 \\
4 \\
10,11,12,16,18,25 \\
6 \\
5 \\
12,22\end{array}$ \\
\hline CUSTOMER ORIENTATION & $\begin{array}{l}\text { Saxe \& Weitz (1982) } \\
\text { Kelley \& Hoffman (1997) }\end{array}$ & $\overline{S Q}$ & $\mathrm{C} / \mathrm{E}$ & $\begin{array}{l}\mathrm{T} \\
\mathrm{E}\end{array}$ & 4,15 \\
\hline $\begin{array}{l}\text { EMPATHY } \\
\text { Care } \\
\text { Concern } \\
\text { Cultural Norms } \\
\text { Mutual Understanding }\end{array}$ & $\begin{array}{l}\text { Parasuraman, Zeithaml, \& Berry (1985) } \\
\text { Parasuraman, Zeithaml, \& Berry (1988) } \\
\text { Mohr \& Bitner (1991) } \\
\text { Cronin \& Taylor (1992) } \\
\text { Johnston (1995) } \\
\text { Price, Arnould, \& Deibler (1995) } \\
\text { Chandon, Leo, \& Philippe (1997) } \\
\text { de Ruyter, Bloemer, \& Peeters (1997) } \\
\text { Wels-Lips, van der Ven, \& Pieters (1998) } \\
\text { Caruana, Ewing, \& Ramaseshan (2000) } \\
\text { Cronin, Brady, \& Hult (2000) } \\
\text { Mishra (2000) }\end{array}$ & $\begin{array}{l}\text { SQ } \\
\text { SQ } \\
\text { SAT } \\
\text { SQ, SAT } \\
\text { SAT } \\
\text { Emotions } \\
\text { SAT } \\
\text { SQ, SAT } \\
\text { SAT } \\
\text { SQ } \\
\text { SAT } \\
\text { SQ }\end{array}$ & $\begin{array}{l}\mathrm{C} / \mathrm{E} \\
\mathrm{C} \\
\mathrm{C} \\
\mathrm{C} \\
\mathrm{C} \\
\mathrm{C} \\
\mathrm{C} / \mathrm{E} \\
\mathrm{C} \\
\mathrm{C} \\
\mathrm{C} \\
\mathrm{C} \\
\mathrm{C}\end{array}$ & $\begin{array}{l}\mathrm{E} \\
\mathrm{E} \\
\mathrm{T} \\
\mathrm{E} \\
\mathrm{E} \\
\mathrm{E} \\
\mathrm{E} \\
\mathrm{E} \\
\mathrm{E} \\
\mathrm{E} \\
\mathrm{E} \\
\mathrm{T}\end{array}$ & $\begin{array}{l}4,7,20,24 \\
4,7,20,24,26 \\
--- \\
4,8,11,19 \\
4 \\
27 \\
9 \\
12 \\
9,12,14,21,22,27 \\
27 \\
10,11,12,16,18,25 \\
---\end{array}$ \\
\hline $\begin{array}{l}\text { RECOVERY } \\
\text { Employees' Response to Failures } \\
\text { Service Failure Recovery } \\
\text { Service Failure Prevention }\end{array}$ & $\begin{array}{l}\text { Berry, Zeithaml, \& Parasuraman (1990) } \\
\text { Bitner, Booms, \& Tetreault (1990) } \\
\text { Bitner, Booms, \& Mohr (1994) } \\
\text { Lytle, Hom, \& Mokwa (1998) } \\
\text { Boshoff \& Allen (2000) } \\
\text { Zeithaml \& Bitner (2000) }\end{array}$ & $\begin{array}{c}\text { SQ } \\
\text { SAT } \\
\text { SAT } \\
\text { SQ, SAT } \\
\text { Recovery } \\
\text { SQ }\end{array}$ & $\begin{array}{l}-- \\
C \\
E \\
E \\
E \\
-\cdots-\end{array}$ & $\begin{array}{l}\mathrm{T} \\
\mathrm{E} \\
\mathrm{E} \\
\mathrm{T} \\
\mathrm{E} \\
\mathrm{T}\end{array}$ & $\begin{array}{l}---- \\
2,13,22 \\
2,13,22 \\
-1- \\
---\end{array}$ \\
\hline
\end{tabular}


Johnston (1995)

Dabholkar, Thorpe, \& Rentz (1996)

de Ruyter, Bloemer, \& Peeters (1997)

Dobni, Zerbe, \& Ritchie (1997)

Wels-Lips, van der Ven, \& Pieters (1998)

Caruana, Ewing, \& Ramaseshan (2000)

Cronin, Brady, \& Hult (2000)

RESPONSIVENESS

Dabholkar, Shepherd, \& Thorpe (2000)

Parasuraman, Zeithaml, \& Berry (1985)

Parasuraman, Zeithaml, \& Berry (1988)

Cronin \& Taylor (1992)

Johnston (1995)

de Ruyter, Bloemer, and Peeters (1997)

Jayasuriya (1998)

Wels-Lips, van der Ven, \& Pieters (1998)

Caruana, Ewing, \& Ramaseshan (2000) Cronin, Brady, \&

Hult (2000)

\section{SPONTANEITY}

Unprompted Employee Actions

Unsolicited Employee Actions

Bitner, Booms, \& Tetreault (1990)

Bitner, Booms, \& Mohr (1994)

Zeithaml \& Bitner (2000)

\section{TANGIBLES}

Parasuraman, Zeithaml, \& Berry (1985)

Parasuraman, Zeithaml, \& Berry (1988)

Cronin \& Taylor (1992)

Johnston (1995)

Appearance

Cleanliness

Convenience

Dabholkar, Thorpe, \& Rentz (1996)

de Ruyter, Bloemer, \& Peeters (1997)

Wels-Lips, van der Ven, \& Pieters (1998)

Caruana, Ewing, \& Ramaseshan (2000)

Cronin, Brady, \& Hult (2000)

Dabholkar, Shepherd, \& Thorpe (2000)

\section{TEAMWORK}

Organisational Citizenship Behaviours

\section{Zeithaml, Berry, \& Parasuraman (1988)}

Berry, Zeithaml, \& Parasuraman (1990)

Morrison (1996)

Baker \& Fesenmaier (1997)

King \& Garey (1997)

1 Dimensions are in bold type with their relevant factors listed below

${ }^{2}$ Since both Satisfaction (SAT) and Service Quality (SQ) are outcomes of the service encounter process, factors influencing either are considered antecedents

${ }^{3} \mathrm{C}=$ customers; $\mathrm{E}=$ employees

5 Ke empirical; $T$ = theoretical

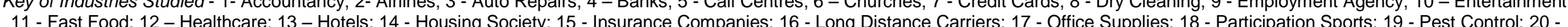
Product Repairs and Maintenance; 21 - Public Transport; 22 - Restaurants; 23 - Retail; 24 - Securities Brokerage; 25 - Spectator Sports; 26 - Telephone Companies; 27 - Tertiary Institutions; 28 -

${ }^{6}$ Although Cronin and Taylor (1992) treated Service Quality as unidimensional through use of the SERVPERF scale, the items used still reflected the five dimensions of SERVQUAL identified by Parasuraman, Zeithaml, and Berry (1988) 